\title{
Do Disasters Discriminate? An Analysis of Economic Loss Incurred in Uttarakhand Disaster 2013 for Different Social Groups
}

\author{
Siba Sankar Mohanty ${ }^{1 *}$, Manoj Kumar Pant ${ }^{2}$, Annie Rath ${ }^{1}$ and Navneet Rajoria ${ }^{3}$ \\ ${ }^{1}$ Department of Analytical and Applied Economics, Utkal University, Bhubaneswar, Odisha, India \\ ${ }^{2}$ Chief Co-ordinating Officer, State Planning Commission, Govt of Uttarakhand, India \\ ${ }^{3}$ Department of Economics, School of Social Sciences and an Intern in the study, India \\ *Corresponding author:ssmoh_1976@yahoo.co.uk
}

\begin{abstract}
From many counts, the natural disaster in Uttarakhand caused by torrential rains in 2013 that had drawn serious attention of policymakers needs an appropriate framework of analysis to account the economic losses incurred. More so because such losses have several implications for the growth of the regional economy on account of its inter-linkages in the production, consumption and distribution processes. The present study adopts a loss assessment framework in four hard hit districts of Uttarakhand and assesses the economic loss of affected districts through both direct and indirect economic loss assessment methods. Apart from this, the present study has tried to capture the gender and the caste differentiated impact of disasters in case of Uttarakhand, to identify the most vulnerable sections and to suggest appropriate measures to reduce their vulnerability in the event of a disaster.

JEL Classification - A1, C4, C8, D6, Q0
\end{abstract}

Keywords: 2013 Uttarakhand disaster, Man-made disaster, Natural disaster, Loss estimation

In June, 2013, the state of Uttarakhand and its adjacent regions witnessed one of the worst disasters since the inception of the State in 2000. The disaster popularly came to be known as the "Himalayan Tsunami" because of the magnitude of loss and devastation, which was comparable only to the 2004 Tsunami in South India. The disaster was probably caused by the flash floods actuated by heavy rainfall and cloudburst in the affected regions of Uttarakhand on 16-17 June, 2013. As per the official estimates by the State Government, and later cited by the India Disaster Report 2013, a total of 4,200 villages were affected, 11,091 livestock were lost and 2,513 houses were completely damaged. More than 70,000 tourists and 100,000 local inhabitants were stranded in the difficult mountain terrain of the upper reaches of the Himalaya. The extent of damage as reported by State Government is depicted in several studies (Satendra, Kumar, \& Naik, 2013).
However, there hardly was any unanimity over the reported loss of human life. For example, while the India Disaster Report 2013 mentioned the death toll at 4190 including those assumed to be dead, the official statements as reported in media mentioned figures like 5700 and 5784 to be dead including those presumed to be dead. As per estimates, 1000 bridges, roads connecting to 13600 villages and 70 hydroelectric projects constituting 505 dams in the state were destroyed in the disaster (UNDMT, 2013). Of all the disaster affected districts in Uttarakhand, four, namely: Rudraprayag, Chamoli, Uttarkashi and Pithoragarh, were worst hit (IRS, 2013).

Unfortunately, there is no comprehensive mechanism available so far to measure the economic loss that can approximate the reality. Moreover, while the losses incurred in disasters are incidental to the larger economy in a macro sense, its short term and long term impacts are felt across population 
groups (especially the marginalized communities) and impinges upon their capacity to adjust with and contribute to the process of mainstreaming. The present paper seeks to highlight the differential economic loss of Uttarakhand Disaster 2013 incurred by different social groups.

\section{A REVIEW OF CONTEMPORARY LITERATURE}

The analytical landscape for impact assessments of natural disasters is not inadequate. But most of them being very context specific, and for very valid reasons, fail to generate a grand principle of economic impact assessment of disasters. Some of these literatures present economic losses as only an addition to the economic cost to the society. So, they consider the deviations from the trend economic activities as the impact of natural disasters (Strobl, 2011; Elliot, Strobl, \& Sun, 2011; Kousky, 2012). These studies however pay little attention to one of the inherent problems in making impact assessments at the microeconomic level. What fails such models in making suitable assessments is the lack of accurate data (more so in the event of disasters). Analysis relying on historical data not only fails to capture the shocks adequately, at times, it may also result in inappropriate conclusions (Yezer, 2000). The literature reviewed for the current study can be broadly classified as those dealing with some of the theoretical debates over the issue of disaster loss estimation, few others that deal with the direct and indirect losses emerging in a disaster, and the rest dealing with methods and tools of measuring the loss and impacts of these disasters.

Over last couple of decades, a number of disciplines such as international development, disaster risk analysis, macroeconomics and public policy, etc., have come forward to understand the linkages between natural disasters and development in an inter-disciplinary framework. Subsequently, questions like "Whether disasters are problem of or for development?" have remained at the forefront of all discussions related to climate change, climate justice and uncertainties related to climate politics (Mochizuki, Mechler, HochrainerStigler, Keating, \& Williges, 2014). The two-way argument that natural hazards and the uncertainties associated with them pose a threat to planning and development processes, and that at the same time, dynamics of development also drive the risk of disasters, is already well established (IPCC, 2012). Empirical evidences and the global trends of disaster management show that not only more and more people are facing disasters in recent years than ever before, also low income countries are likely to suffer more due to a disaster than the high income countries due to their lack of ability to adjust against large external shocks (IPCC, 2012; Ferreira, Hamilton, \& Vincent, 2013; Mochizuki, Mechler, Hochrainer-Stigler, Keating, \& Williges, 2014; IMF, 2012). As evidence suggests, lower income countries face only around 11 percent of all natural hazards such as earthquakes, cyclones, floods, and droughts etc. Yet, more than 53 percent of all loss of life due to disasters occurs in these countries (UN, 2010).

Different academic disciplines are able to explain a range of theoretical debates surrounding the issue of disasters. However, all these studies can be classified into two broad types based on their approach to the relationship between disasters and development: ex-ante studies and ex-post studies. Ex-ante studies usually have a tendency to include economic geography, development studies, public finance and policy etc., as its core contributing disciplines. They have focused on drivers of disaster risk creation, role of institutions in creating disasters, problems of collective action, issues of corruption and misappropriation of funds, role of different political regimes, loss of public funds due to policy interventions and so on. Ex-post studies include macroeconomic implications of natural disasters (Anbarci, Escaleras, \& Register, 2005; Escaleras, Anbarci, \& Register, 2007; Costa, 2012; Mochizuki, Mechler, Hochrainer-Stigler, Keating, \& Williges, 2014).

Direct economic loss includes damage to homes and contents, damage to firm structures, inventory, and contents, damage to infrastructure, mortality and injury, environmental degradation, emergency response and clean-up, etc. (Kousky, 2012). These losses include 'structural and nonstructural damage, costs of relocation, losses to business inventory, capital-related losses, income losses, rental losses and cost of repair for lifelines' (Wong et al. 2005). Indirect economic loss includes business interruption (for those without direct damage, multiplier effects, costly adaptation or utility reduction from loss of use, mortality and morbidity 
(Kousky, 2012). Disasters also have a bearing on employment (Arlikatti, Lindell, \& Prater, 2006) and to some extent, result in permanent changes in the household income and consumption patterns.

Yet some other notable literature do look at the issues of direct and indirect costs or losses of disasters in different ways. Some authors have attributed spatial and temporal dimensions to the direct and indirect economic losses incurred due to a disaster. To further simplify, spatial aspect of economic loss is subdivided into local and non local impacts of disaster. And, temporal aspect highlights the short term and long term costs due to a disaster (Greenberg, Lahr, \& Mantell, February 2007; Hallegatte \& Dumas, 2009; Hallegatte \& Przyluski, 2010; Zhujun \& Jiuping, 2013; Nader, Ali, \& Rezaei., 2012). Some studies include policy aspects such as climate adaption policy costs to be a direct cost of the disaster (Kousky, 2012).

In previous studies economic losses suffered due to a disaster have been estimated using different kinds of economic models such as (i) Microeconomic models at the household level (e.g., Dercon, 2004), (ii) Econometrics models at the local level (Guimaraes, Hefner \& Woodward, 1993; Bertinelli \& Strobl (2010); Albala-Bertrand, 1993; Skidmore and Toya, 2002; Hallegatte \& Przyluski, 2010), (iii) Input-output (IO) models at the regional or national level (e.g., Gordon et al., 1998; Okuyama and Chang, 2004; Hallegatte, 2008), (iv) Computable General Equilibrium (CGE) models at the regional or national level (Rose et al. 1997; Rose, 2007; Rose and Liao, 2005, Rose, 2007; Tsuchiya et al. 2007; Hallegatte \& Przyluski, 2010; Okuyama, 2008), (v) Hybrid Models (Hallegatte \& Przyluski, 2010; Hallegatte, 2008, Horridge et al. 2005; Booker, 1995; Holden and Shiferaw, 2004), (vi) Idealized Models (Hallegatte \& Dumas, 2008; Hallegatte \& Ghil 2008), (vii) Public Finance Coping Capacity frameworks (Hallegatte \& Przyluski, 2010) and (viii) Network-production systems (Haimes and Jiang, 2001; Henriet and Hallegatte, 2008).

Disasters affect different population groups differently depending on their socio-economic and cultural positions in the social space. Some prominent literature such as (Forgette, Dettrey, Mark, \& Swanson, 2009) focus on the continuity of social capital and the elements of social isolation to be major determinants in establishing diversities in perceptions about loss and its recovery both in physical as well as societal terms (Albala-Bertrand, 2009). Thus, not only do disasters have differentiated social impacts, disaster management policies may also have differentiated implications for men and women, for rich and the poor and for different social groups. There have been many attempts to study these implications and present estimations for the differences across social groups. Most popular among these attempts have used econometric tools to compare the policy implications across groups. The literature on methodology of such analyses extend from analysis of simultaneous causality as developed by Cowels led econometricians to fixing and conditioning approaches that are being used more recently in contemporary literature (Heckman, James J; Edward, Vytlacil J, 2007).

There are yet other studies that focus on further detailing of the said differential impact. For example, UN-ECLAC, (2003) further bifurcates the impact of disasters on women into direct and indirect damages (UN-ECLAC, 2003). The study by Neumayer \& Plümper, (2007) emphasizes that natural disasters reduce the life expectancy of women more than that of men. This conclusion was attributed to the knowledge that since female life expectancy is usually higher than that of males, for some nations natural disasters thin the gender gap in life expectancy. We acknowledge, however, that much more inter-disciplinary research between medical and social scientists is needed to fully understand the interplay between mortality and gender in the presence of natural disasters (Neumayer \& Plümper, 2007).

While a substantive review of literature may constitute an interesting research area itself, the primary aim of our study is to present an economic loss analysis of the Uttarakhand disaster 2013 in the context of different social groups and there are not much research available on this study topic apart from some divergent views on the reporting of the damages made by various organizations.

\section{DATA AND METHODS}

With a total area of $53,484 \mathrm{~km}^{2}, 93 \%$ of Uttarakhand is mountainous and $65 \%$ of its area is covered in forests. High Himalayan peaks and glaciers cover most of the northern part of the state. Located at the foothills of the Himalayan mountain ranges, Uttarakhand has international boundaries with 
China (Tibet) in the north and Nepal in the east. On its north-west lies the state of Himachal Pradesh, while to its south lies Uttar Pradesh. The state is rich in natural resources especially water and forests with many glaciers, rivers, dense green cover and snow-clad mountain peaks. Uttarakhand is home to two major rivers Yamuna and Ganga. Dehradun is the provisional Capital of Uttarakhand. According to the 2011 census of India, Uttarakhand has a population of $10,116,752$ with a population density of 189 people per square kilometer and a sex ratio of 963 females per 1000 males. There are 13 districts in Uttarakhand which are grouped into two divisions, Kumaon and Garhwal. Kumaon division consists of six districts namely Almora, Bageshwar, Champawat, Nainital, Pithoragarh, Udham Singh Nagar, whereas, the Garhwal division comprises of the districts of Dehradun, Haridwar, Tehri Garhwal, Uttarkashi, Chamoli, Pauri Garhwal, Rudraprayag.

Uttarakhand is one of the fastest growing states in India. The real GSDP grew at $13.7 \%$ (CAGRCompounded Annual Growth Rate) during the FY2005-FY2012 period. Per capita income in Uttarakhand is INR82, 193 (FY 2012) which is higher than the national average of INR60,603 (FY2012) (MOSPI, 2012). According to the Reserve Bank of India, the total foreign direct investment in the state from April 2000 to October 2009 amounted to US\$ 46.7 million.

Agriculture is one of the most significant sectors of the economy of Uttarakhand, not unlike the rest of India. Basmati rice, wheat, soybeans, groundnuts, coarse cereals, pulses, and oil seeds are the most widely grown crops. Fruits like apples, oranges, pears, peaches, litchis, and plums are widely grown and important to the large food processing industry. Litchis, horticulture, herbs, medicinal plants, and basmati rice have their own agricultural export zones set up in the state. $86 \%$ of all croplands lie in the plains while the remaining on the hills. However, given the majorly hilly terrain, the yield per hectare is not very high.

Uttarakhand owns a history of disaster occurrences and as per the 2013 CAG report on the performance audit of disaster preparedness in India, there had been a substantial loss of life (approx. 653) due to various disasters in the state since last five years prior to the 2013 disaster (CAG, 2013). Yet, the state lacked in undertaking appropriate planning and preparedness efforts essential for expedient disaster management. The frequency and intensity of various disasters had not been identified in Uttarakhand. Furthermore, the State Disaster Management Authority formulated in 2007 had not met even once since its creation, indicating at the dysfunctionality of state authorities in managing disasters. Moreover, there was no state plan for early disaster warning and communication in place. Also, the report found several irregularities in the management of state disaster response fund. Besides, there had been no training for the staff engaged in disaster prevention, mitigation and management at district, block and village levels or for the medical personnel for dealing with mass scale emergencies such as disasters. Despite enough warning about the state's hazard prone status there was no adequate preparedness or plan to deal with Uttarakhand disaster 2013 (CAG, 2013). It is believed that if the warnings and performance report by CAG had been heeded to, then the incidence and the loss of Uttarakhand disaster 2013 could have been minimized. Hence, the occurrence of Uttarakhand disaster 2013 has been credited to manmade factors.

The present study is primarily focused on Uttarkashi, Chamoli, Rudraprayag and Pithoragarh districts of Uttarakhand, which apparently were the worst hit districts in the disaster. The study is largely based on primary data collected from 652 sample respondents through the instrument of a personal interview schedule, which was finalized after undertaking a pilot survey in Mundhan and its nearby villages in the district of Dehradun. The sample selection procedure was network (snowball) sampling method. In the present paper, analysis through descriptive statistics is made to highlight the differential impacts of the disaster on specific population groups.

\section{ESTIMATED LOSS IN UTTARAKHAND DISASTER 2013}

In the year 2016, the Directorate of Economics and Statistics, Government of Uttarakhand came out with a comprehensive mapping of the Disaster 2013. The report of the Directorate of Economics and Statistics highlighted that 1037 villages were affected in six districts of Uttarakhand in the Disaster. These six districts were: Uttarkashi, Chamoli, Rudraprayag, Pithoragad, Bageswar and 
Table 1: Damage of Basic Facilities in 1037 Affected Villages in Uttarakhand Disaster 2013

\begin{tabular}{lcc}
\hline $\begin{array}{c}\text { Nearest Available Common Services/Comfort } \\
\text { and Other Facilities }\end{array}$ & $\begin{array}{c}\text { Number of Villages with Facilities } \\
\text { Affected in 2013 Disaster }\end{array}$ & $\begin{array}{c}\text { Number of Villages still Facing } \\
\text { Facilities in Damaged Condition } \\
\text { after 2 Years post Disaster }\end{array}$ \\
\hline Daily/Evening Market & 23.82 & 8.10 \\
Weekly Market & 15.62 & 0.00 \\
Daily needs/Provision Store & 16.49 & 4.34 \\
Wheat/Flour Mill & 15.91 & 4.73 \\
Aanganwadi Centre & 7.62 & 2.12 \\
Primary School & 9.26 & 3.86 \\
Junior High School & 14.56 & 4.24 \\
Higher Secondary School & 20.35 & 6.17 \\
Primary health centre/Sub-centre/Community & & 4.82 \\
Health Centre & 24.11 & 3.95 \\
Medicine/Chemist shop & 23.92 & 4.34 \\
Private Clinic/Doctor & 24.59 & 0.00 \\
District Hospital & 39.73 & 3.66 \\
Animal Hospital/Pharmacy & 27.10 & 4.82 \\
Post-office/ Sub Post office & 21.41 & 5.01 \\
Police station/ Revenue Police station & 27.29 & 3.86 \\
Gram Panchayat Office & 15.72 & 0.00 \\
Block Development Office & 30.86 & 7.23 \\
Co-operative Society & 28.06 & 3.18 \\
Bank & 27.87 & 0.00 \\
Tehsil/Sub-Tehsil Office & 32.21 & 0.00 \\
District Headquarter & 40.31 & 2.89 \\
Godown & 29.99 & 0.00 \\
APMC/Mandi & 25.07 & 6.94 \\
STD/PCO/WWL Telephone & 24.20 & 5.79 \\
Electricity & 16.49 & 0.48 \\
Other Services & 1.93 & \\
\hline Source:DES & & \\
\hline
\end{tabular}

Source: DES 2016.

Haridwar. Highest number of villages were affected in Uttarkashi (359) followed by Pithoragad (243), Rudraprayag (206), Chamoli (84), Haridwar (95) and Bageswar (50). It is worth noting that in all these districts, a majority of the villages that were directly affected in the disaster were the ones that were far off from a motorable road. As per the type of disaster faced, landslides constituted the major type of manifestation of the Uttarakhand Disaster 2013 followed by the loss of land due to the change in the course of river. Around 34.6 percent villages faced loss of land due to change in the course of river.

In terms of loss of human lives, majority of the people who died in Uttarakhand Disaster 2013 were from states other than Uttarakhand. From Uttarakhand, it has been reported that 680 persons had died in the disaster of which 630 were from Rudraprayag only. Around five percent residential units were fully or partially damaged in the Uttarakhand Disaster 2013. Of the total 7629 houses fully or partially damaged in the state, a majority was in Chamoli where around 22.5 percent of all residential units were damaged. The disaster also affected the common peoples' access to market. The number of villages with a nearby market within one kilometre, were reduced by 4.2 percent. In most cases this happened because the market places were shifted to safer places or they could not be restored after the disaster due to other reasons.

An estimated 1491.287 hectares of land was lost of which the majority were agricultural land. Around 6.39 percent of irrigated and 7.9 percent un-irrigated 
Table 2: Livelihood Option wise Percentage of Families Affected in Uttarakhand Disaster 2013.

Sources of Livelihood

Sources of Livelihood

Mule Riders

Pilgrims/Tourist : In Carrying Baggage/Other Stuff

Pilgrimes/Tourist: Residing for Other Works like

Waiter, Guard, Hawkers, Small Entrepreneur

Pilgrims/Tourist: For Working within the Villages

Temple Work

Self Agricultural Activities

Labor: Agri/Horticulture

Labor: Non-Agriculture

Daily Wage

Small Business within Village

Small Business outside Village

Cow/Buffalo Breeding

Forest Related

Depends on Assistance

Providing House and Other Equipments on Rent

Pension

Others

Source: Compiled from the DES Report.

land available for cultivation in the affected villages were damaged or lost due to erosion and land slide in Uttarakhand disaster 2013.

A study of the livelihood options of the inhabitants of the six affected districts (Table 2) reveals that in the disaster of 2013, professions closely associated with tourism and pilgrimage activities have faced the major blow. From among the families wholly dependent on a particular job, the highest loss of livelihood has been in case of the profession of carrying baggage/other stuff of tourists/pilgrims - about 79.6 percent of all the families solely dependent on it for livelihood, have been adversely affected in the disaster. This is followed by those involved in working for tourists/pilgrims within their villages. Among the families which were dependent on more than one particular job for livelihood, about 80.9 percent of the families earning partial livelihood through being waiters, guards, hawkers or small entrepreneurs related to tourism/ pilgrimage activities have been adversely affected, followed very closely by the tourist/pilgrims' baggage ferrying group (80.3 percent), making these stand out as the worst hit partial-livelihood sources. The cause could be attributed to the steep reduction in the number of tourists post the disaster owing to the fear instilled in the minds of the people, the impairment of road connectivity and the direction by government limiting the number of pilgrims per day to a specific number.

As per the official records, during the disaster and its aftermath, a total of 59487 individuals in the state of Uttarakhand received aid, both in the form of cash and kind, through relief and rehabilitation programmes amounting to ₹ 7637.96 lakh (90.5 percent of all aids and relief) from the government exchequer. From the total number of beneficiaries of aid, a major chunk was from Uttarkashi district, while the proportions of beneficiaries from the remaining three districts were more or less same (Table 3).

\section{Analysis of Primary Information on Disaster Loss in Uttarakhand Disaster 2013}

In this study, we have taken a sample of 652 respondent households from five districts of Uttarkhand of which four were badly hit by the disaster and the Dehradun district was taken as a controlled area suitable for comparison. It has to be mentioned here that although Dehradun was not 
Table 3: Aid Received through Relief and Rehabilitation Programme in Uttarakhand

\begin{tabular}{cccc}
\hline Relief and Aid received for & $\begin{array}{c}\text { Number of } \\
\text { Individuals } \\
\text { Receiving Aid }\end{array}$ & $\begin{array}{c}\text { Total Aid Received in the } \\
\text { Form of Cash/Kind Materials } \\
\text { from Government (in Lakhs) }\end{array}$ & $\begin{array}{c}\text { Share of Aid Received } \\
\text { from Government (in } \\
\text { Percentage) }\end{array}$ \\
\hline Fully Damaged House & 432 & 1241.13 & 97.9 \\
Acutely Damaged House & 1534 & 984.3 & 96.9 \\
Partially Damaged House & 2271 & 977.2 & 94.9 \\
Livestock loss & 207 & 27.67 & 76.3 \\
Other Losses & 55043 & 4407.67 & 86.1 \\
\hline Total & 59487 & 7637.96 & $\mathbf{9 0 . 5}$ \\
\hline
\end{tabular}

Source: Compiled from the DES Report.

directly hit by the disaster 2013, but the economic impacts were felt in the district due to many forward and backward linkages that the district has with the directly affected districts. The composition of our sample respondent families include 143 households each from Chamoli and Uttarkashi, 151 households from Rudraprayag and 153 respondent households from Pithoragad district. From Dehradun district, we have taken 62 respondent households. In addition to the Dehradun district, we have also taken some limited controlled samples from each affected districts that did not have any direct loss of assets or lives due to disaster 2013, but felt the economic impact in several ways.

A social group wise classification of sample respondents shows that in the total sample covered, around 53 percent respondents are from the upper caste category, 20 percent from $\mathrm{OBC}, 18$ percent from SC and 8 percent from ST categories. Our analysis also takes into consideration the age, education and occupational structure while computing differential impact of the disaster. When it comes to resilience against disasters, proportion of youth in the family, proportion of educated family members and occupational structure of the working class and the composition of the labour force also matter a lot. For example, there are some occupations in which income and employment are not affected by disasters. In some occupations there are benefits from disasters and some are hard hit. A disaster being an external shock, occupational structure in the disaster hit areas contribute in defining the gainers and losers from the disaster.

Overall, almost half of the respondent family members are non-workers and around 17 percent are engaged in unpaid family work. Around 1.2 percent are engaged as casual workers in
MGNREGS projects and 4.6 percent are engaged as casual workers otherwise. Around 7.2 percent are in salaried job both in private and government and around 20.2 percent are engaged as self-employed in agriculture or other petty businesses. Social group wise, highest proportion of community engaged as salaried workers are from General community, 8.9 percent, compared to lower participation from $\mathrm{OBC}$ and ST groups. Highest proportion of nonworkers are from General and ST communities (53 percent and 49 percent respectively) although nonworkers from other groups are also not substantially lower. Highest proportion of members engaged in unpaid family work are from ST communities (approximately 22.5 percent) while only around 15.5 percent workers from General community are engaged in unpaid family work. Proportionately, more workers engaged as casual workers both in MGNREGS and otherwise, are from SC communities in the study districts.

When it comes to workforce participation rate (WFPR), female respondent family members in our study area perform significantly less than their male counterparts. In Chamoli district, compared to 53 percent WFPR for male members, women have only 27 percent participation rates. In Dehradun district, female members have only around 8 percent participation rate compared to 44 percent for their male counterparts. In Pithoragad, the figures are 41 percent for male and 16 percent for females. In Rudraprayag, WFPR for the male was 53 percent compared to 26 percent for females. In Uttarkashi, the WFPR for male are female respondent family members were 47 percent and 20 percent respectively. Overall, in all the study districts, female workforce participation rate was 20 per cent compared to around 48 per cent for the 
male respondent family members.

\section{Estimation of Direct Loss to Different Social Groups Due to 2013 Disaster}

As the available literature suggested, direct loss in case of disasters manifest in terms of loss of assets, loss of employment and loss of livelihoods in the form of sources of income or employment. Since our study focuses on the discriminatory impact of disasters on different social groups, it is pertinent to have a comparative analysis for the gender and the caste groups. We shall start with the impact on employment situation in the aftermath of Uttarakhand Disaster 2013.

In Figure-1, we have presented a sex wise distribution of average loss of employment in number of days in study districts. Even with lower participation of the female workers in the labour force, the average loss of employment of the female was higher than the male invariably in all the study districts. In Chamoli, compared to an average loss of 10 days of employment for male, the average loss of employment for the female was 27 days. The overall loss of employment in the district was 17 days for the entire sample respondents. In Rudraprayag, compared to an average loss of less than 10 days of employment for male, the average loss of employment was more than 29 days for the female. The overall loss of employment in the district was 17 days for the entire sample respondents. In Uttarkashi, compared to an average loss of 20 days of employment for male, the average loss of employment was 32 days for the female. The overall loss of employment in the district was 24 days for the entire sample respondents. In Pithoragad, compared to an average loss of 20 days of employment for male, the average loss of employment was 28 days for the female. The overall loss of employment in the district was 22 days for the entire sample respondents. In Dehradun, compared to an average loss of 17 days of employment for male, the average loss of employment was 34 days for the female. The overall loss of employment in the district was 20 days for the entire sample respondents. In the entire sample, compared to an average loss of 15 days of employment for male, the average loss of employment was 29 days for the female. The overall loss of employment in the district was 20 days for the entire sample respondents. Uttarakhand being a state with a very conservative socio-cultural set up, women do go out for working for a wage itself indicates a situation where the households are hard pressed for resources. This is not to say that in Uttarakhand, women do not work. They would rather contribute in household unpaid economic activities than working for a wage. So, a higher loss of employment for the female would mean an additional distress of the families that are low in resources.

Sex wise average income loss in the study area suggest that in Chamoli and Rudraprayag, the average income loss for women far exceeds their male counterparts. While in Chamoli, the income loss was on average ₹ 1823 for men and ₹ 2823 for the women, in Rudraprayag, it were ₹ 1615 for the men and ₹ 4129 for the women (Fig. 4). In Pithoragad, men lost ₹ 3823 and the women lost ₹ 2383 on average. In Dehradun, Men lost $₹ 7560$ and the women lost ₹ 5671 worth of income during the disaster.

Fig. 1: Sex wise Distribution of Average Loss of Employment in Number of Days in Study Districts

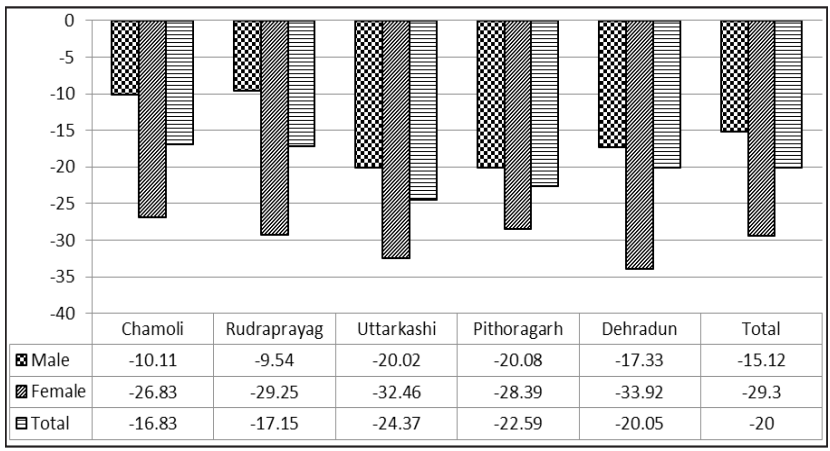

Source: Based on Primary Data collected from the field

A noteworthy observation here is that the district of Dehradun which was not directly hit by the disaster, had a substantial loss of employment. This might be because of the inter-linkages and the disturbances in the supply chains that linked economic activities in Dehradun with the disaster hit districts through trade and other channels. So, disasters do not just impact locally, they do have a macroeconomic character. However, the case of Dehradun is also special in Uttarakhand as it is a gateway to the entire state, especially the Garhwal region and its economic activities are bound to get affected due to a temporary halt in the tourism, trade and other activities. A future study on these specificities of 
Dehradun might be of interest in academic and policy terms for regional development.

Fig. 2: Magnitude of Loss of Employment for Female Workers

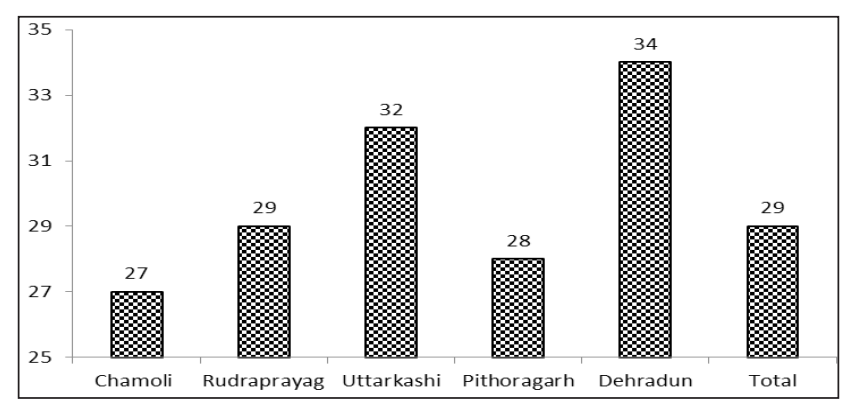

Source: Based on Primary Data collected from the field.

Fig. 3: Loss of Employment for Female Workers as a Multiple of the Loss to Male Workers in Number of Times

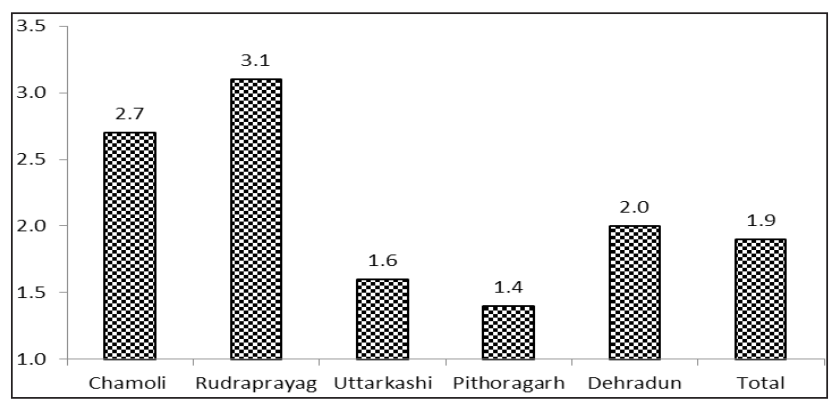

Source: Based on Primary Data collected from the field.

Fig. 4: Sex wise Average Income Loss in Study Districts

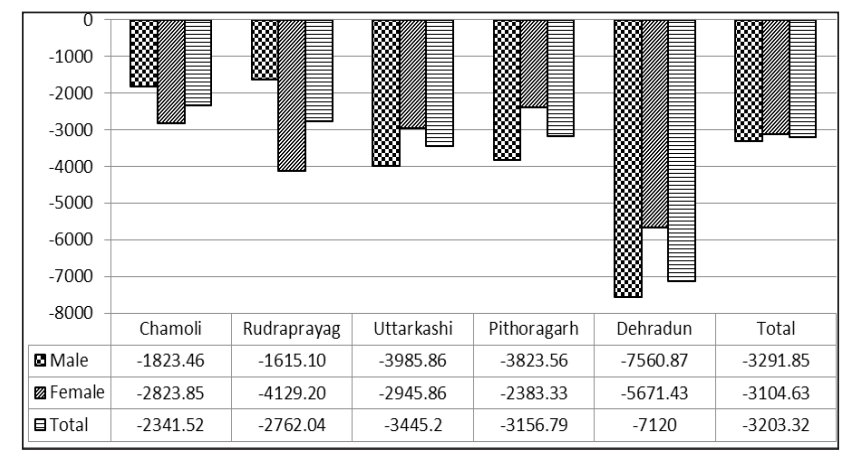

Source: Based on Primary Data collected from the field.

A social group wise analysis of the number of days of work lost due to Uttarakhand Disaster 2013, as depicted in Fig. 5, shows that in Chamoli district, members from the ST community suffered the maximum loss of employment (27 days) followed by those from OBC category (17 days), General category (16 days) and SC category (13 days) respectively. In Rudraprayag district, members from the ST community suffered the maximum loss of employment (more than 30 days) followed by General (22 days), OBC (18 days) and SC (3days) communities. In Uttarkashi district, members from the General community suffered the maximum loss of employment (more than 27 days) followed by OBC category (26 days), ST category (19 days) and SC category (17 days). In Pithoragad district, members from the General community suffered the maximum loss of employment (more than 28 days) followed by OBC (24 days), ST (22 days) and SC (14 days) category respondents. In Dehradun district, members from the General community suffered the maximum loss of employment (more than 27 days) followed by respondents from the SC (15 days) and OBC (10 days) categories. There were no respondents from ST community in our sample from Dehradun. Overall, members from the ST community suffered the maximum loss of employment of more than 26 days followed by General category respondents ( 24 days), OBC category respondents (18 days) and SC category respondents (12 days).

Fig. 5: Social Group wise Distribution of Average Loss of Employment in Number of Days in Study Districts

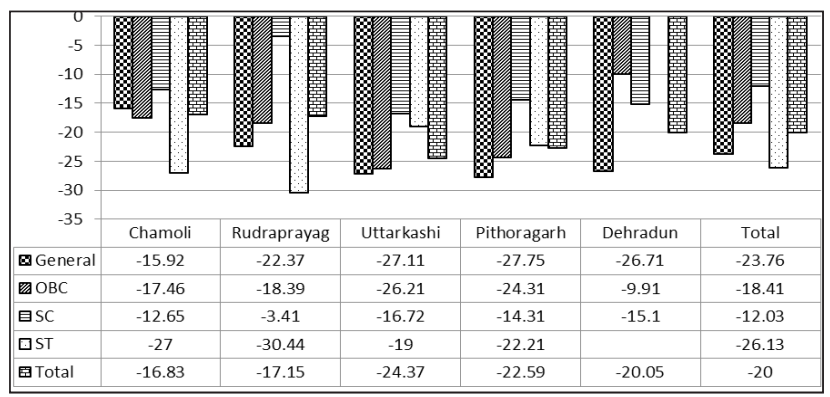

Source: Based on Primary Data collected from the field

Social group wise, average income loss has been highest for respondent families belonging to General category, which is also much higher than average income loss for all the groups on the whole. Among the four worst hit districts, respondent family members from General category have had maximum average income loss in Pithoragad, while those from OBC and SC groups suffered maximum average income loss in Uttarkashi, and those from ST groups suffered maximum average income loss in Rudraprayag. However, as an exception, SC respondents in Rudraprayag have had a gain in income, as has been captured in Fig. 6 . 
Fig. 6: Social Group wise Average Income Loss in Study Districts

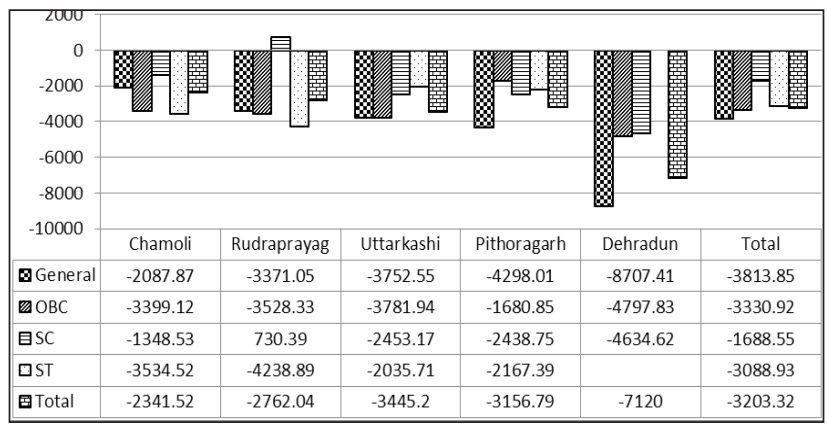

Source: Based on Primary Data collected from the field

The study reveals that overall, the incidence of loss of land has been highest in case of ST families, with 80 percent of the total number of ST households surveyed in the four worst hit districts reporting loss of land in the disaster, followed somewhat closely by SC households (Fig. 7). In Chamoli and Uttarkashi, all the ST households surveyed apparently had lost land in the disaster. Even in the district of Pithoragad, the highest incidence of land loss has been in case of ST families. Only in Rudraprayag district, the incidence of land loss among SC households has been substantially higher than that of ST households.

Fig. 7: Social Group wise Percentage of Households Who Suffered loss of Land in Study Districts

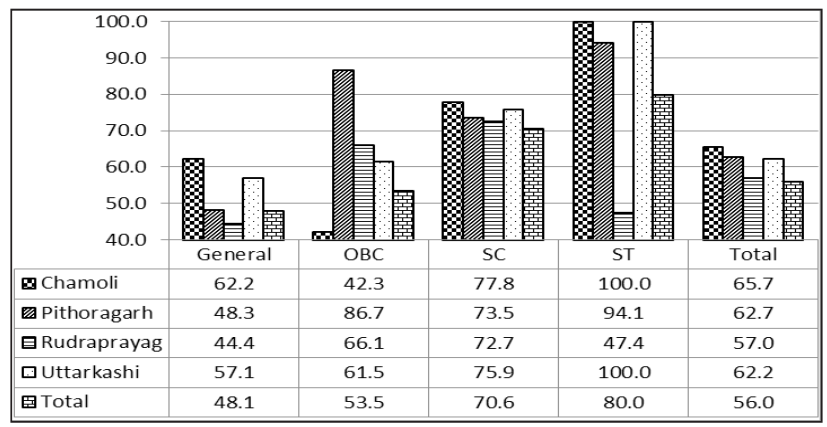

Source: Based on Primary Data collected from the field.

In terms of land lost as proportion of total land holding (owned), although the loss to the families of the general community was highest, it is only marginally higher than the loss to the ST communities. Except for Pithoragad, in all other districts, the land lost as percentage of total land held by SC and ST population was higher than their general and OBC counterparts, as can be observed from Fig. 8.
Fig. 8: Social Group wise Land Lost as Percentage of Total Land Owned in Study Districts

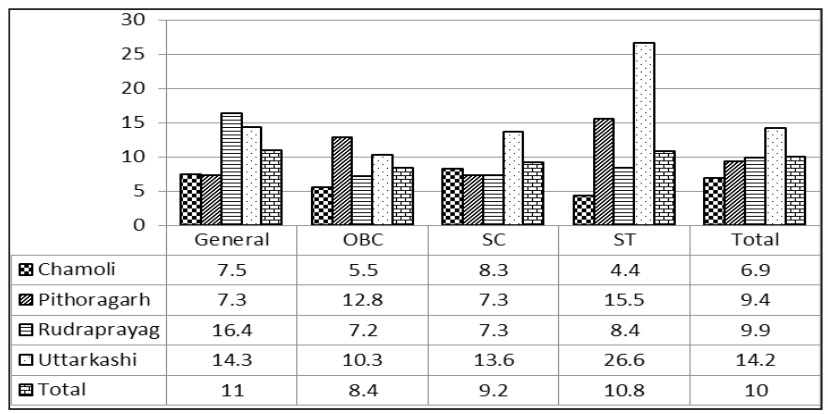

Source: Based on Primary Data collected from the field

Among the four social groups, the proportion of families who suffered a loss of livestock in the 2013 disaster out of the total number of families who had raised a livestock, is highest (84.6 percent) in case of the social group ST. District wise, the percentage of families who suffered a loss of livestock out of the total number of families who had raised a livestock, is highest in case of respondent families belonging to General category in Chamoli district, but highest in case of ST respondent families in the other three districts (Fig. 9).

Fig. 9: Social Group wise Incidence of Loss of Livestock (Percentage of Families Who Suffered a Loss of Livestock out of Total Number of Families Who Had Raised a Livestock)

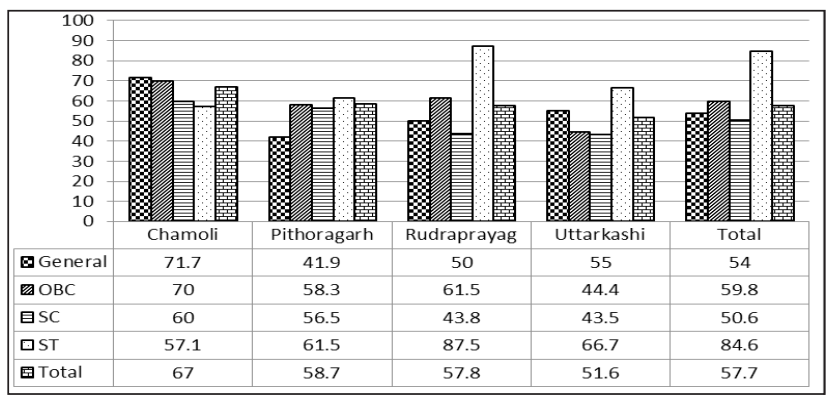

Source: Based on Primary Data collected from the field.

Among the respondent households from the four social groups, overall, the incidence of damage to construction and buildings has been highest in case of ST households (11.3 percent) followed closely by OBC households (9.3 percent), while the incidence of damage in case of General and SC respondent households is more or less similar (6.9 percent and 6.3 percent respectively) and is relatively lower. In Chamoli and Pithoragad districts, the incidence of loss is highest in case of ST respondent households while in case of Rudraprayag and Uttarkashi districts it is highest in case of $\mathrm{OBC}$ respondent 
households, and in Uttarkashi district apparently none of the ST respondent households suffered any damage to construction and buildings (see Fig. 10). Surprisingly however, the value of damaged construction and buildings assessed as a percentage of the total value of their assets, is highest in case of $\mathrm{OBC}$ respondent households while it is quite lower in case of SC and ST respondent households (see Fig. 11).

Fig. 10: Social Group wise Percentage of Respondent Households Facing a Damage to Construction and Buildings

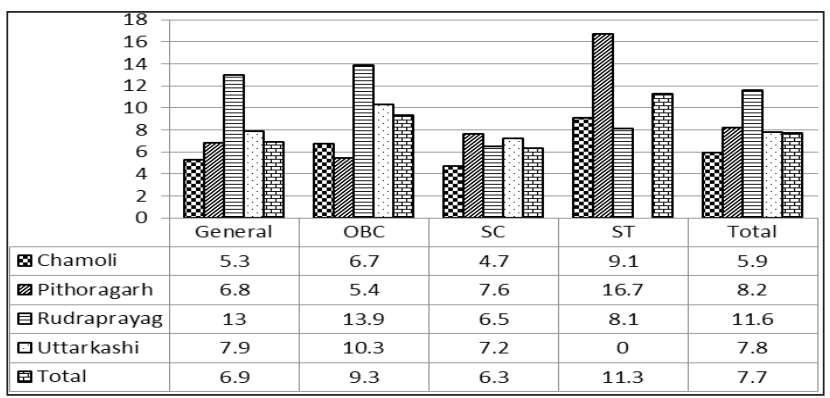

Source: Based on Primary Data collected from the field

Fig. 11: Social Group wise Value of Construction and Building Damaged as Percent of Total Value of Assets

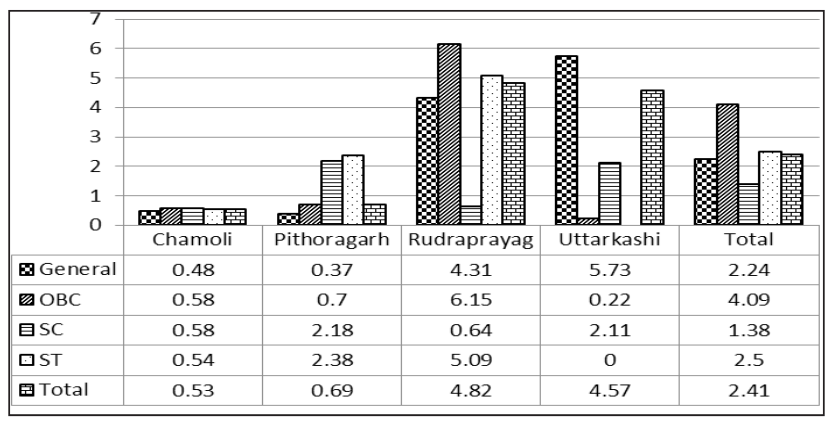

Source: Based on Primary Data collected from the field.

We have computed direct economic loss as the sum of income loss (or employment loss), value of the land lost, loss of livestock, loss of construction and buildings and the increase in indebtedness as a consequence of the disaster. As discussed earlier, loss of income is the loss incurred due to the loss of employment in number of days multiplied with the potential income foregone due to the loss of employment. Loss of land, which is a critical factor of production in rural Uttarakhand is the loss in the productive use of the land manifested by the value of the land that became unusable or the amount spent on reclaiming the land in its earlier use. Cultivable land is scant in Uttarakhand as only around one seventh of the total geographical area of the State is available for cultivation. In hilly areas, land is prepared laboriously by building corridors of stone walls, steps, water channels, etc. and the process of preparation of a cultivable land takes generations of effort and care to become and remain cultivable.

So, any damage to land requires a substantial amount of money to get repaired and the poorer sections usually repair such damage in a piece meal approach or abandon the land as the economic returns from such repair is significantly less than the amount invested in repair. So, although, it is difficult to gather information on the loss of land, we have used the amount spent so far since the disaster for the repair of land as a proxy for the amount lost. However, this is only an underestimation of the actual loss. Livestock loss is computed from the difference in the value of the livestock before and after the disaster. Similar to the case of land, we have used the amount spent on repair of building and construction as a proxy for the loss of construction and buildings.

Fig. 12: Average Direct Economic Loss Incurred to Respondents in Study Districts

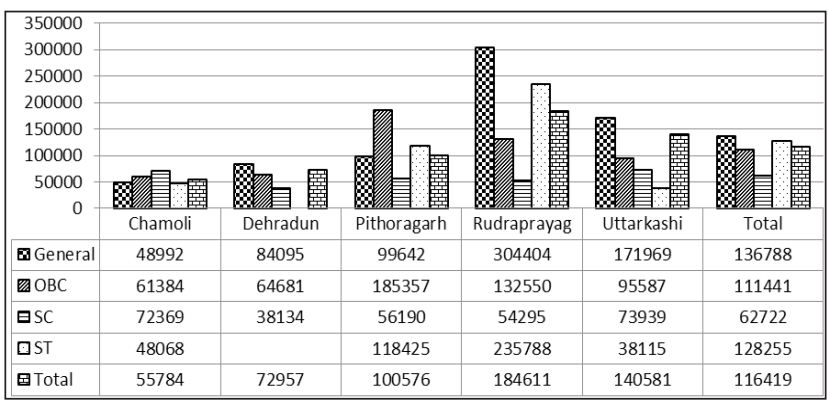

Source: Based on Primary Data collected from the field.

However, such an estimation is again an underestimation. Finally, the incidences of indebtedness in the aftermath of the disaster both in the form of cash loan and kind loan are used as loss due to disaster because no matter whatever be the purpose of such borrowing, in a disaster hit situation, a significance part of this borrowing would be spent on mitigating the effects of disaster on the personal wellbeing of the respondents. Fig. 12 through Fig. 14 present the district and social group wise average direct loss incurred by the families due to Uttarakhand Disaster 2013.

It seems that the respondents from the General category suffered the maximum average direct 
economic loss in the Uttarakhand Disaster 2013. While the aggregate loss in the disaster was ₹ 136788 for the General category respondents, it was followed by ₹ 128255 for the STs and ₹ 111441 for the members of the OBC community. For the members of the SC community, the average loss was ₹ 62722 in all the districts. In Chamoli, SCs suffered the maximum average loss whereas, in Pithoragad, the STs suffered the maximum loss in absolute terms that included the amount borrowed in the aftermath of the disaster.

Fig. 13: Social Group wise Average Indebtedness

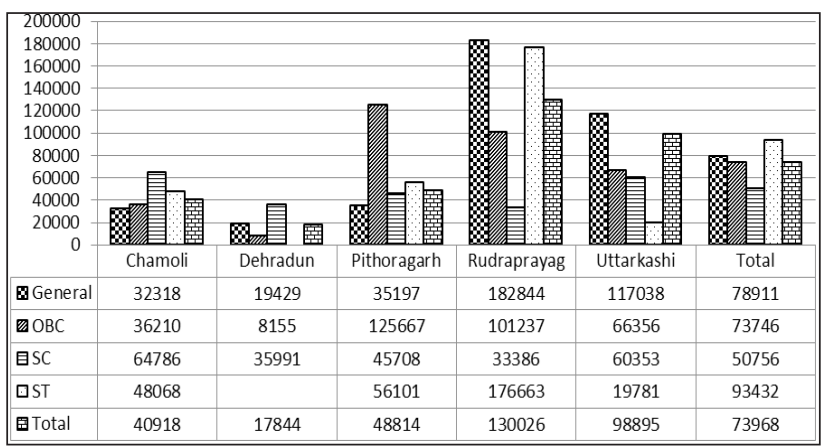

Source: Based on Primary Data collected from the field.

Fig. 14: Direct Loss as Percent of Annual Family Income

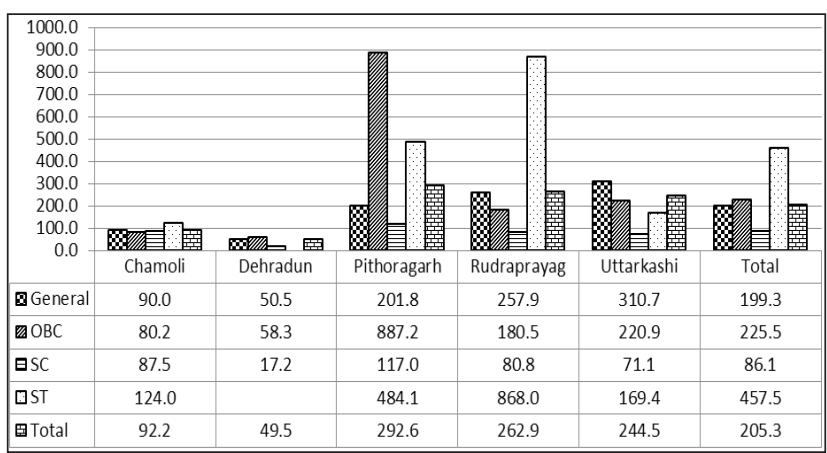

Source: Based on Primary Data collected from the field.

If we ignore the amount borrowed, it is the members of the ST community who suffered the maximum loss in the Uttarakhand disaster 2013, followed by the members from the General community and the $\mathrm{OBC}$ community. In Chamoli, the members of the SC community suffered the maximum average loss of ₹ 64786 followed by a loss of ₹ 48068 by the members of the ST community compared to an average loss of $₹ 40918$ by all the communities. In Dehradun, it is the members of the SC community who suffered a loss of ₹ 35991 vis-à-vis a direct loss of ₹ 17844. In Pithoragad, both the OBC and the
ST community members suffered more loss in the disaster compared to the overall district average. In Uttarkashi, members from the General community suffered the maximum loss.

As a percentage of annual family income, the direct loss was around 457 percent for the members of the ST community for the entire sample compared to the overall average of 205 percent. Although the figures varied, the pattern of relative loss to the communities remained the same as our previous analyses. In Chamoli and Rudraprayag, members from the ST community were the worst hit. In Dehradun and Pithoragad, the members of the OBC community were the worst hit while in Pithoragad, the STs also had a proportionate loss more than the district average. In Uttarkashi, the members from the General category were the worst hit.

\section{CONCLUSION}

The above analysis suggests that even with lower participation of the female workers in the labour force, the average loss of employment of the female was higher than the male invariably in all the study districts. Social group wise, in Chamoli and Rudraprayag districts, members from the ST community; and in Uttar Kashi and Pithorahad districts, members from the General community suffered the maximum loss of employment. Overall, members from the ST community suffered the maximum loss of employment. Uttarakhand is a typical state with large domination of upper caste communities and these are the communities that have participated in most of the economic activities including trade and business. In specific regions, even people from socially upper strata are categorized as scheduled due to the regional backwardness. For example, all the SC community members in the Mundhan village of Dehradun are actually Brahmins and other upper caste people scheduled as SCs due to the extreme backwardness of the village. People from ST community are largely manual workers or petty gatherers who have suffered a loss of employment due to a sudden downward shock in the economic condition of their potential employer communities and a temporary backward shift in the demand by the overall society for the commodities they gather from forests. For example, many women from the ST community actually earn an income by selling 
firewood collected from forests. But due to disaster, when need for firewood gathered from forest was temporarily stalled, women from ST community might have suffered a loss of employment. Similar might be the case with wage employment of male members. However, it is clearly visible from the data we analyzed that the loss of employment in Uttarakhand due to disaster 2013 is different for different communities in different districts. The incidence of loss of land has been highest in case of ST families, followed somewhat closely by SC households. In terms of land lost as proportion of total land holding (owned), except for Pithoragad, in all other districts, the land lost as percentage of total land owned by SC and ST population was higher than their General and OBC counterparts. The marginalized groups (SCs and STs) are also the groups to have suffered the maximum loss in terms of livestock.

To sum up, the Uttarakhand disaster 2013 did affect different social groups in different manners. While the disaster was bad for the entire population its impact on the socially marginalized groups was higher than the groups in the mainstream.

\section{ACKNOWLEDGEMENTS}

The present paper draws substantially from a research study titled "Economic Loss in Disasters and the Differentiated Impact on the Wellbeing of Social Groups: Developing a Methodological Tool for Loss and Impact Assessment in the Context of Uttarakhand-2013 Natural Disaster" sponsored by the Indian Council for Social Science Research (ICSSR) under its sponsored programme during 2015-17. The authors are thankful to ICSSR for the financial support to undertake the research activity.

\section{REFERENCES}

Albala-Bertrand, J. 1993. Political economy of large natural disasters: with special reference to developing countries. Oxford University Press.

Albala-Bertrand, J.M. 2009. Responses to Complex Humanitarian Emergencies and Natural Disasters: An Analytical Comparison. Third World Quarterly, 215-227.

Anbarci, N., Escaleras, M. \& Register, C. A. 2005. Earthquake fatalities: the interaction of nature and political economy. Journal of Public Economics, 89: 1907-1933.

Arlikatti, S., Lindell, M.K. \& Prater, C.S. 2006. Risk area accuracy and hurricane evacuation expectations of coastal residents. Environment and Behavior, 38(2): 226-247.
Bertinelli, L. \& Strobl, E. 2010. Quantifying the economic damage due to hurricane strikes.

Booker, J.F. 1995. Hydrologic and economic impacts of drought under alternative policy responses. Water Resources Bulletin, 31: 889-906.

CAG. 2013. Report No. 5 of 2013 - Performance Audit of Civil Disaster Preparedness in India of Union Government. New Delhi: CAG, Ministry of Home Affairs.

Costa, S. 2012. Government Repression and the Death Toll from Natural Disasters, CESifo Working Paper No. 3703. Retrieved from Social Science Research Network. : https://papers. ssrn.com/sol3/papers.cfm?abstract_id=1990191

Dercon, S. 2004. Growth and Shocks: Evidence from Rural Ethiopia. Journal of Development Economics, 309- 329.

DES. 2016. Uttarakhand Mein Gram Star Per Apdaown ka Prabhav - Study on Impact at Village Level After 2013 Disaster, Directorate of Economics and Statistics, Government of Uttarakhand.

Elliot, R.J., Strobl, E. \& Sun, P. 2011. The Local Impact of Typhoons on Economic Activity in China: A View from Outer Space. Department of Economics Discussion Paper 15-11.

Escaleras, M., Anbarci, N. \& Register, C.A. 2007. Public sector corruption and major earthquakes: a potentially deadly interaction. Public Choice, 132: 209-30.

Ferreira, S., Hamilton, K. \& Vincent, J.R. 2013. Does development reduce fatalities from natural disasters? New evidence for floods. Environment and Development Economics, 18(6): 649-679.

Forgette, R., Dettrey, B., Mark, B.V. \& Swanson, D.A. 2009. Before, Now, and after: Assessing Hurricane Katrina Relief. Population Research and Policy Review, 28(1): 31-44.

Gordon, P., Richardson, H. \& David, B. 1998. Transportrelated impacts of the northridge earthquake. Journal of Transportation and Statistics, 21-36.

Greenberg, M.R., Lahr, M. \& Mantell, N. 2007. Understanding the Economic Costs and Benefits of Catastrophes and Their Aftermath: A Review and Suggestions for the U.S. Federal Government. Risk Analysis, 83-96.

Guimaraes, P., Hefner, F. \& Woodward, D.P. 1993. Wealth and Income Effects of Natural Disasters: An Econometric Analysis of Hurricane Hugo. In NETC, Review of Regional Studies (pp. 97-114). [Emmitsburg, MD]: [National Emergency Training Center], 1993.

Haimes, Y. \& Jiang, P. 2001. Leontief-based model of risk in complex interconnected infrastructures. Journal of Infrastructure Systems, 7: 1-12.

Hallegatte, S. 2008. An adaptive regional input-output model and its application to the assessment of the economic cost of Katrina. Risk Analysis, 779-799.

Hallegatte, S. and Ghil, M. 2008. "Natural Disasters Impacting a Macroeconomic Model with Endogenous Dynamics", Ecological Economics, 68: 582-592.

Hallegatte, S. \& Dumas, P. 2009. Can natural disasters have positive consequences? Investigating the role of embodied technical change. Ecological Economics, 68: 777-786. 
Hallegatte, S. \& Przyluski, V. 2010. The Economics of Natural Disasters. Retrieved from The CESifo Group, consisting of the Center for Economic Studies (CES), the ifo Institute and the CESifo $\mathrm{GmbH}$ (Munich Society for the Promotion of Economic Research): https://www.cesifo-group.de/ DocDL/forum2-10-focus2.pdf

Heckman, James J., Edward, Vytlacil J. 2007. Econometric Evaluation Of Social Programs, Part I: Causal Models, Structural Models And Econometric Policy Evaluation. Retrieved March 20th, 2016, from Yale University: https:// economics.yale.edu/sites/default/files/cv_vytlacil.pdf

Henriet, F. and Hallegatte, S. 2008. Assessing the Consequences of Natural Disasters on Production Networks: a Disaggregated Approach, FEEM Working Paper No. 100.

Holden S. and Shiferaw B. 2004. Land degradation, drought and food security in a less-favoured area in the Ethiopian highlands: a bio-economic model with market imperfections. Agricultural Economics, 30: 31-49.

Horridge, M., Madden, J. and Wittwer, G. 2005. The impact of the 2002-2003 drought on Australia. J. Policy Modeling, 27: $285-308$.

IMF. 2012. Natural Disasters Hitting More People, Becoming More Costly. . Retrieved December 1, 2017, from International Monetary Fund: https://www.imf.org/en/ News/Articles/2015/09/28/04/53/sonew101012a

IPCC. 2012. Special Report on Managing the Risks of Extreme Events and Disasters to Advance Climate Change Adaptation (SREX). Intergovernmental Panel on Climate Change (IPCC).

IRS. 2013. Uttarakhand flash floods - A report by Indian Redcross Sociery, 27.06.2013. Retrieved December 21, 2017, from http://www.indianredcross.org/press-rel27-june2013.htm

Kousky, C. 2012. Informing Climate Adaptation: A Review of the Economic Costs of Natural Disasters, Their Determinants, and Risk Reduction Options. Retrieved July 2017, 11, from Inter American Development Bank: http://www20.iadb. org/intal/catalogo/PE/2013/10871.pdf

Mochizuki, J., Mechler, R., Hochrainer-Stigler, S., Keating, A. \& Williges, K. 2014. Revisiting the 'disaster and development' debate - Toward a broader understanding of macroeconomic risk and resilience. Climate Risk Management, 3: 39-54.

Nader, M., Ali, A. \& Rezaei, R. 2012. Effects of the Bam earthquake on employment: a shift-share analysis. Disasters, 36(3): 420-38.

Neumayer, E. \& Plümper, T. 2007. The gendered nature of natural disasters: the impact of catastrophic events on the gender gap in life expectancy, 1981-2002. Annals of the Association of American Geographers, 97(3): 551-566.

Okuyama, \& Chang, S.E. 2004. Modeling Spatial and Economic Impacts of Disasters. Heidelberg: Springer.
Okuyama, Y. 2008. Critical review of methodologies on disaster impact estimation. https://www.gfdrr.org/sites/gfdrr/files/ Okuyama_Critical_Review.pdf: Background Paper for Joint World Bank - UN Assessment on the Economics of Disaster Risk Reduction.

Rose, A. \& Liao, S. 2002. Modeling regional economic resiliency to earthquakes: a computable general equilibrium analysis of lifeline disruptions, Department of Energy, Environmental, and Mineral Economics, The Pennsylvania State University, University Park, PA.

Rose, A. 2002. Model validation in estimating higher-order economic losses from natural hazards, in Taylor C, VanMarcke E (eds.) Acceptable Risk to Lifeline Systems from Natural Hazard Threats, New York: American Society of Civil Engineers.

Rose, A., Benavides, J., Stephanie, E., Chang, P. \& Lim, D. 1997. The Regional Economic Impact of an Earthquake: Direct and Indirect Effects of Electricity Lifeline Disruptions. The Journal of Regional Science, 37(3): 437-458.

Satendra, Kumar, A.K. \& Naik, V.K. 2013. India Disaster Report 2013. New Delhi: National Institute of Disaster Management (NIDM).

Skidmore, M. \& Toya, H. 2002. Do natural disasters promote long-run growth? Economic Inquiry, 664-684.

Strobl, E. 2011. The Economic Growth Impact of Hurricanes: Evidence from U.S. Coastal Counties. Review of Economics and Statistics, 575-589.

Tsuchiya, S., Tatano, H. \& Okada, N. 2007 Economic loss assessment due to railroad and highway disruptions. Economic Systems Research, 19(2): 147-162.

UN. 2010. Natural Hazards, Unnatural Disasters: The Economics of Effective Prevention. World Bank Publications.

UNDMT. 2013. Uttarakhand Flash Floods: Situation update $2^{\text {nd }}$ July 2013. Retrieved December 02, 2017, from http:// peoplesscienceinstitute.org/PDF's/Uttarakhand $\% 20$ Disaster/SIT\%20REP\%20-\%205\%20Uttarakhand \%20 Floods\%2001\%20July\%202013\%20(UNDMT).pdf

UN-ECLAC. 2003. Handbook for Estimating the Socio-economic and Environmental Effects of Disasters. United Nations.

Wong, I., Bouabid, J., Graf, W., Huyck, C., Poru, A. \& Silva, W. et al. 2005. Potential Lossesin a Repeat of the 1886 Charleston, South Carolina Earthquake. Earthquake Spectra, 21(4): 1157-1184.

Yezer, A.M. 2000. The Economics of Natural Disasters. Washington DC: Center for Economic Research, Discussion Paper No. 98-11. George Washington University.

Zhujun, L. \& Jiuping, X. 2013. An economic loss assessment framework after Wenchuan earthquake. Disaster Advances, 6(5): 67-77. 